\title{
AGRICULTURAL COOPERATIVES IN HORTICULTURE VALUE CHAIN
}

Umurzakov Uktam Pardaevich,

Doctor of economic sciences, Professor Tashkent Institute of Irrigation and

Agricultural Mechanization Engineers

E-mail: uktam.umurzakov@gmail.com

\section{Eshmatov Sirojiddin Keldiyarovich}

PhD student of Tashkent Institute of Irrigation and Agricultural Mechanization Engineers E-mail: seshmatov@gmail.com

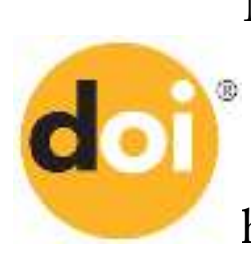

http:/ / dx.doi.org/10.26739/2573-5616-2018-1-2-11

Abstract: Based on activity type, national conditions and other factors, different types of cooperatives may be founded and their goals and functions may deffere respectively. The International Cooperative Alliance describes the cooperative as follows: "A cooperative is an autonomous association of persons united voluntarily to meet their common economic, social, and cultural needs and aspirations through a jointly owned and democraticallycontrolled enterprise." Cooperatives are businesses owned and run by and for their members. Whether the members are the customers, employees or residents they have an equal say in what the business does and a share in the profits. As businesses driven by values not just profit, cooperatives share internationally agreed principles and act together to build a better world through cooperation. Cooperatives were useful for promoting the interests of the less powerful members of society. Farmers, producers, workers, and consumers found that they could accomplish more collectively than they could individually.

Generalization of scientific results 
This article describes problems of fruit and vegetable production, postharvest management and marketing systems in value chain and discusses the importance of the agricultural cooperatives for solving these issues.

Keywords: horticulture, agricultural cooperatives, vegetable production, problems of fruit.

\section{Introduction}

The emerging of value chain is considered because of the competition among enterprises to take better position and be more competitive than other producers in the market. The value chain approach the first time was introduced by American scholar Porter in 1985 in his book "The Competitive Advantage: Creating and Sustaining Superior Performance". According to Porter, the value chain is the set of different activities and each enterprise's acitivity is divided into main and supporting activities. In each step of the activity, the certain amount of cost is added and the whole processes create the value chain.

Nowadays, modern enterprises are not only competing with single enterprises, but also competiting among value chains and they need to competitive by setting mutual cooperation (Mei, Han and Chen, 2009). Farmers and processing companies understand that since there is strong competition in the market, they individually cannot meet price and quality requirements of the customers. In this regard, farmers try cooperating with other actors of the value chain to regulate joint operations, exchange of experiences, cost decrease, qulity improvement, to take stronger market position and eventually to increase the profit entire the the value chain. In horticulture value chain- farmers, suppliers, processors, and all other participants who are involved to deliver ready products to the final consumers are strategic partners. When they cooperate closely then they can minimize the risk and increase profitability.

Agricultural Cooperatives provide their members necessary raw materials, services and support on directions such as production, harvesting, transportation, sorting, processing, storage, selling products and other types of services. Cooperatives came about in difficult economic and social circumstances in the 19th century. Farmers where gradually discovering that though joining forces, they could improve their access to markets and jointly finance vital complementary activities, namely: procurement, research, processing, marketing, distribution and promotion (European Agricultural Cooperatives report, 2010). Agricultural cooperatives help producers assure Generalization of scientific results 
markets and supplies, achieve economies of scale, and gain market power through jointly marketing, bargaining, processing, and purchasing supplies and services. Today's agricultural cooperatives, large and small, are an important part of the global market. They have formed marketing agenciesin-common to jointly export their products, and continue to serve their members by looking for growth opportunities and the use of new technologies. The mission of cooperatives, however, always remains the same-to serve members.

\section{Literature review}

Business environment is chaning very fast and so it is requiring new product-service innovations, product variety, high quality, quick supporting services and others to satisfy the consumers. To meet consumer expectations demands from all participants of the value chain many efforts such as hard work, continuous marketing research, investments and other different measures (Walters and Rainbird, 2007).

Under such circumstances, it is crucial to introduce business models that meet the interests of both producers and consumers. In developing countries, small farmers are facing difficulties because of hard competition with big farmers and processing companies. This limits their involvement in the value chain (Hanf, 2014).

One of the problems facing farmers in their income generation is the availability of a marketing chain that has many middle buyers (merchants) and other participants. To get more profit by buying products from farmers at a low price and and selling them at a higher price is the main goal of these merchants. This situation is not only useless for farmers who sell their products at low prices, but also for end-consumers who purchase expensive products (Dardak, 2015).

Cooperating within the cooperative is the process of gaining new experiences. It is important that value chain actors have a strong desire to engage in partnership and learning within the cooperative and think about long-term profit rather than short term goals. At the same time, the agreement between farmers and cooperatives reflects the rights and obligations of the parties and increases mutual trust by monitoring quality and quantity control from the initial stages of production to the final sale (Popovic, 2013).

According to the University of California Cooperative Extension Service, Agricultural Cooperatives provide producers (farmers) and other value chain stakeholders services such as to have potential customers for Generalization of scientific results 
their products, increase the quantity and quality of their production, joint marketing, processing, pricing and use strong advantage by using cooperative services. Today, there are more than 3,000 agricultural cooperatives in the U.S., with 2.8 million memberships, a total net income of nearly $\$ 1.2$ billion and net business volume of more than $\$ 96$ billion (University of California Cooperative Extension Service 2017. Marketing, supply, and service cooperatives are the most common types of agricultural cooperatives.

Marketing cooperatives assemble, pack, process, and sell members' products in both domestic and foreign markets. The level of service provided depends on member needs and the product.

Supply cooperatives purchase products and services for their members. They make large-scale purchases of fuel, seed, fertilizers, and crop protectants and pass their cost-savings on to members.

Service cooperatives provide members with specialized services, such as horticultural advice and others, which are usually not economical for an individual farmer to obtain.

Another main category of the service cooperative is credit cooperative that supports its member's co-finance investments and capital investments. That is, the funds generated by the members' capital may be given as credit to its members of the cooperative or to others (Ruete, 2014).

Additionally, there are bargaining cooperatives, which are often called bargaining associations. They bargain or negotiate with processors and other first handlers for better prices and terms of trade for their producer-members.

Because of merging within the cooperative and using all available capacities improve productivity, quality, and sales and ultimately increases the profit of the market actors. In case of the Netherlands, the volume of the production produced by farmers is remaining unchanged despite the fact that the numbers of farmers decline year by year. In 2015, there were 60,000 farmers and total generated value by production, processing and procurement consisted of $€ 50,0$ billion (Bijman, 2016). The cooperatives have much share in this value added production.

\section{Research findings}

Fruit and vegetable production and processing specialized cooperatives have the largest share in the Agricultural Cooperatives and their share consist of $95 \%$ in the marklet. Market share of agricultural cooperatives is average $40 \%$ while it is $70 \%$ in the Netherlands (Bijman, 2016). 
In 2001, European Union had 132,000 cooperatives with 2,3 mln employees and they have much influence in agriculture (Makri et al., 2011).

According to the General Confederation of Agricultural Cooperatives of the European Union (COGECA report 2015), in 1996 the share of the cooperatives in agriculture was 83\% in Netherlands, 79\% in Finland and 55\% in Italy. Research shows (Shurnik and Vihriala, 1999) that in 1999 there were 30,000 agricultural cooperatives with 12,0 mln members in European Union and their share consisted of more than $50 \%$ of production and $60 \%$ of the collecting, processing and marketing operations. While in 2014, there were 21,769 agricultural cooperatives with $6,2 \mathrm{mln}$ members and their total turnover was $€ 347,3$ billion. The total number of employees were 660,000 and average turnover per agricultural cooperative was $€ 16,0 \mathrm{mln}$.

The following table-1 provides information on the number of Agricultural Cooperatives in some EU member states and number of their members, total trade turnover as of 2014.

Table-1

\begin{tabular}{|l|c|c|c|}
\hline \multicolumn{1}{|c|}{ Countries } & $\begin{array}{c}\text { Number } \\
\text { of } \\
\text { agr.cooperatives }\end{array}$ & $\begin{array}{c}\text { Number } \\
\text { of members }\end{array}$ & $\begin{array}{c}\text { Turnover } \\
\text { (mln Euro) }\end{array}$ \\
\hline Italy & 5834 & 862323 & 34362,0 \\
\hline Spain & 3844 & 1179323 & 25696,0 \\
\hline France & 2400 & 858000 & 84350,0 \\
\hline Germany & 2400 & 1440600 & 67502,0 \\
\hline Hungary & 1116 & 31544 & 1058,0 \\
\hline Croatia & 613 & 10734 & 167,0 \\
\hline Czech Republic & 548 & 524 & 1327,0 \\
\hline Lithuania & 402 & 12900 & 714,0 \\
\hline Netherlands & 215 & 140000 & 32000,0 \\
\hline England & 200 & 138021 & 6207,0 \\
\hline Ireland & 75 & 201684 & 14149,0 \\
\hline Denmark & 28 & 45710 & 25009,0 \\
\hline
\end{tabular}

Source: General Confederation of Agricultural Cooperatives of the European Union, Report of 2015

Makre and others (2011) mentions (based on Nelsen and Scolbe, 2006) that model of PEST (Political Economic Socia-cultural Technology) is the useful tool for agricultural cooperatives environment analysis. And in this model each factor has direct or indirect effects on the development and successful functioning of the cooperatives. For example, technological factors Generalization of scientific results 
are very important for creating new products and developing manufacturing processes.

Quality control is very crucial to agricultural cooperatives (Hobbs and others, 2002) and they always try to improve their image by meeting the customers' needs (Hendrikse, 2004). One of the main objectives of the cooperatives is to improve the position of their members in existing markets, to enter new ones, to assist launching of the new products and services, to reduce costs and increase profit (Burt, 2004).

Today, Agricultural Cooperatives remain an important part of the global market and continue to seek development opportunities for their members. Establishing contacts with Agricultural Cooperatives also creates favorable conditions for fruit and vegetable processing enterprises. That is, enterprise get high-quality and reliable raw materials in continues base. In addition, the products that they obtained for processing will be produced by the confidential seeds which are delivered to the farmers under the strict control of cooperative, not from poor quality seeds of different grades.

Farmers will get support from cooperatives in aspects such as getting high quality seeds, chemicals, raw materials; professional agricultural services, finding customers, reliable partners and eventually interest for production increase. All above mentioned advantages ensure that different parties act more efficiently and effectively at different stages of the value chain. Therefore, documents which constitute the legal basis of the cooperative activities are very important. There are a number of benefits for farmers and processors by joining cooperatives such as increase production and sales, access to new markets, get high-quality cheap services, use new technologies and market data. Due to the cooperation within the cooperative, production volume grows, logistics and marketing activities have got positive effect. Additionally, large number of essential raw materials or services purchased for the members within the cooperative will be much cheaper and will save costs for each actor of the value chain.

If the interrelated activities are not merged well enough and have weak relationships between them, then the potential profit will not be as high as it should be. Because, in today's rapidly changing market condition, being competitive and productive depends on how fast adapt and response to the market's price, quality, technology and safety requirements (Bijman et al. 2011).

Improper post-harvest management on storage and processing of the fruit and vegetable products decreases quality and eventually affects Generalization of scientific results 
negatively the profit of all value chain participants. Such negative impacts can be reduced and managed by improving supply chain through cooperating with the Agricultural Cooperatives. Coordination of transportation activities within the cooperatives will prevent value chain actors from products losses, quality distortion, extra loading-unloading and spending costs.

Chart-1

The largest seven European fruit and vegetable cooperatives.

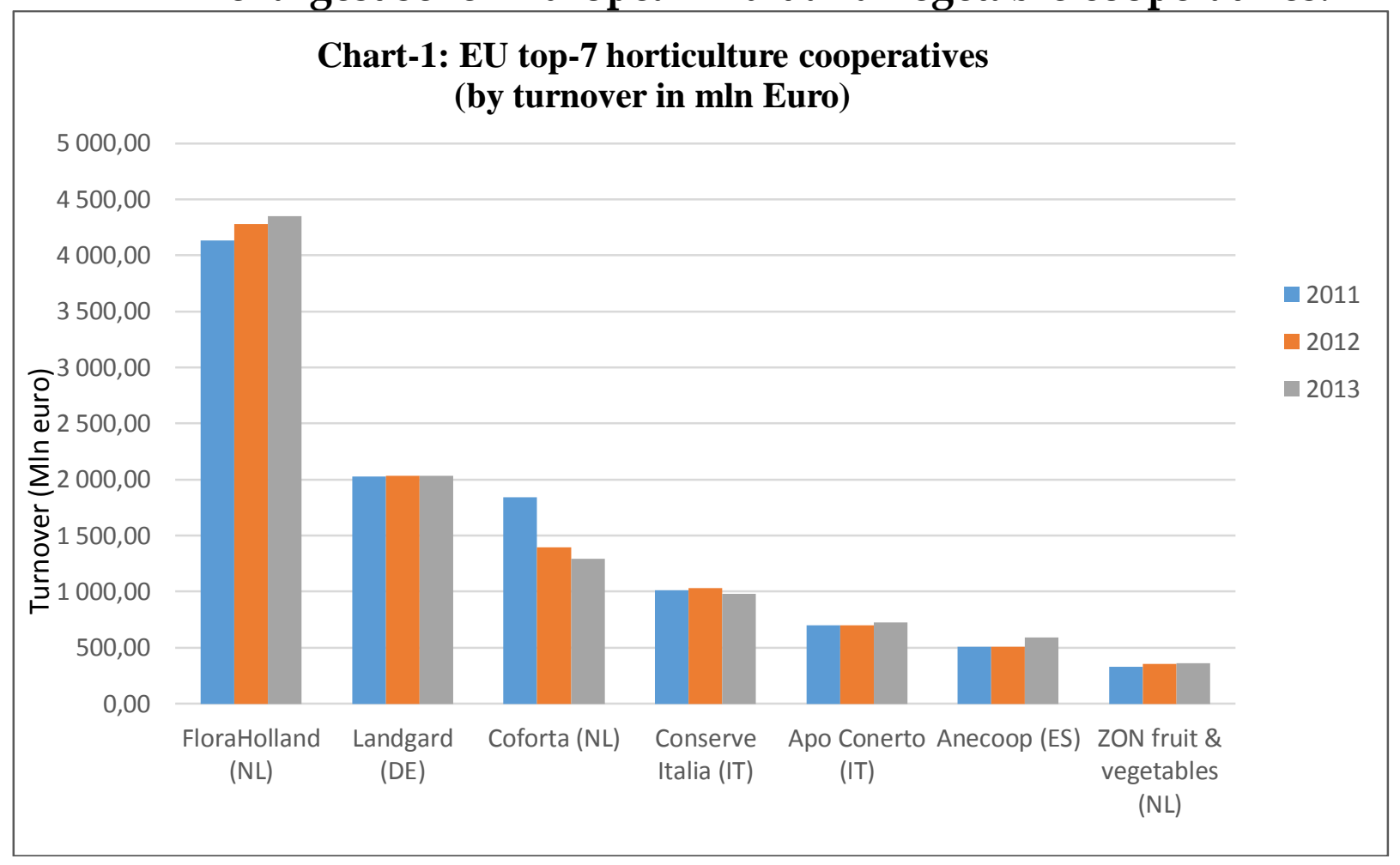

Source: Development of the agricultural cooperatives in the EU for 2014. Copa-Cogeca report, Brussel. 2015

According to the Lurry Burt (2004), the active involvement members (owners) in sphere of capital investment, decision making and research is crucial for the further development of the cooperatives. They should come with different suggestions to improve the cooperatives, encourage members and all interested parties to use more cooperative services. In addition, the board of directors elected by the members should ensure that work force, capital and resources are properly managed and should set goals and control their implemention appropriately. Good training and professional development of cooperative members and employees will not only improve the quality of products, but also improve the image of cooperative for public Generalization of scientific results 
and partners. Generally, highly qualified professionals who have both theoretical and practical experience serve cooperatives. These specialists are managers, supervisors, consultants, marketers and official agents. They know the requirements, needs, changes in the markets and establish contacts or agreements with different organizations on behalf of cooperatives and farmers. This will save farmers time and money and enable them to produce more and higher quality products.

Keep in mind that cooperatives do not solve all the problems. Joining to the cooperative does not mean that you are able to sell low quality products at high price, access markets easily, find customers without much effort and etc. On the contrary, cooperatives provide their members with useful information, suggestions to improve product/service quality, produce new products, provide services, mediate on behalf of members and provide other supports.

There are not favorable environment for the development of the cooperatives in many countries. In particular, the lack of a comprehensive legal framework for co-operatives, much government control over cooperatives, the existence of various restrictions and the lack of cooperative conception among farmers. Creation of practical conditions, providing the independence of cooperatives in management and ownership and presenting economic privileges are major impetus for the development of the Agricultural Cooperatives. In addition, co-operative registration, auditing and reporting systems should be as simple and transparent as possible.

Chart-2 shows the factors that influence the development of cooperatives based on the survey (Makre et al. 2011) which was conducted among 30 Agricultural Cooperatives. It can be seen that creation of a legal framework for the cooperative activities has a major impact $(18 \%)$ on the development of co-operatives. 


\section{Chart-2. Development Factors of Agricultural Cooperatives}

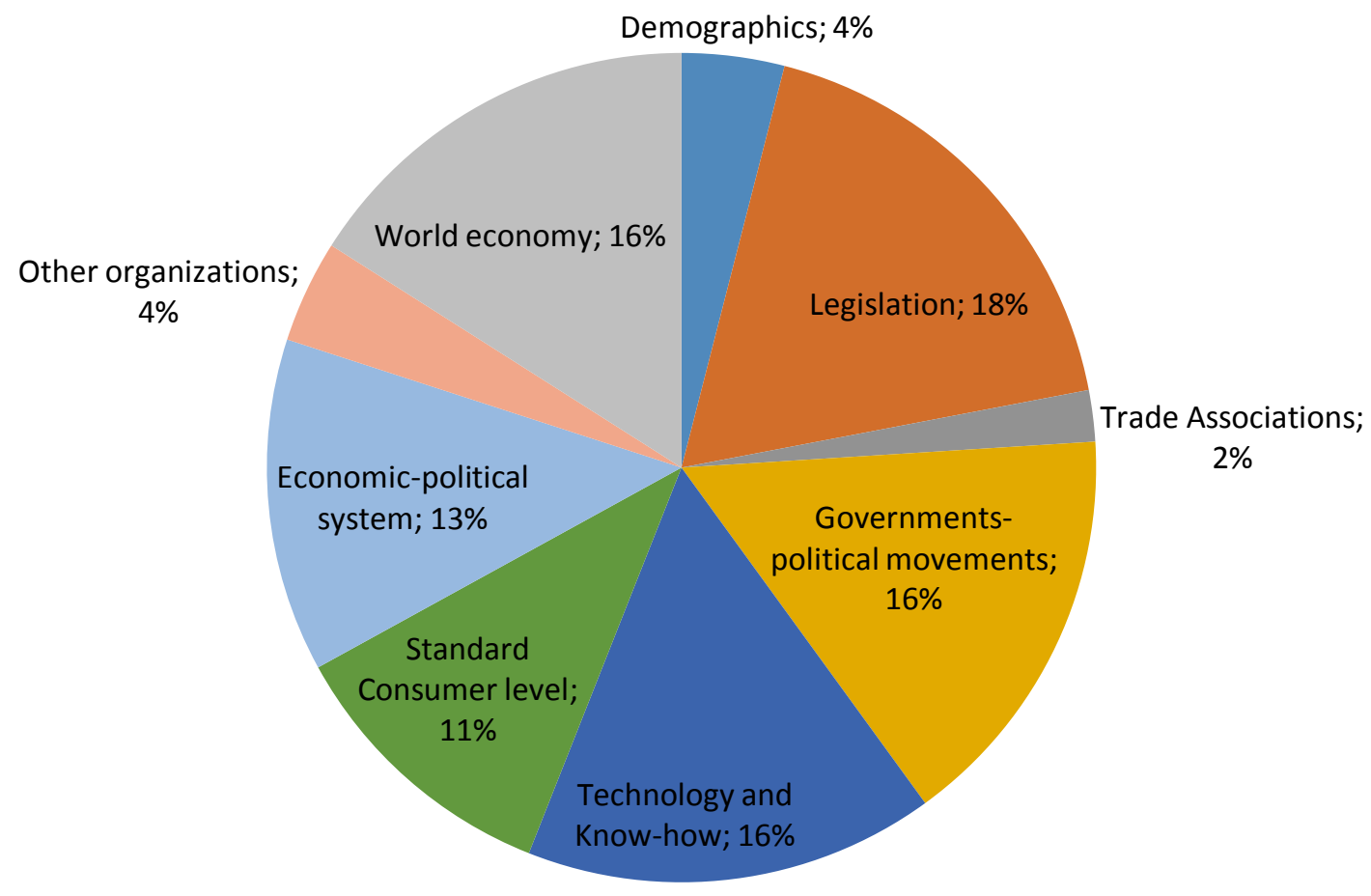

Source: Makre et al. 2011

Approach to the Agricultural Cooperatives varies in developed and developing countries since farmers and producers work together in different stages of the value chain and gain different experiences (Hanisch, 2009). For example, in developing countries cooperatives are seen as a tool for farmers to access to the markets while in developed countries they are seen as means to strengthen the current and future market position and compete with other producers in major international markets. In both cases, economies of scope, quality and price indicators are extremely important.

In our opinion, the establishment and development of the Agricultural Cooperatives in case of Uzbekistan as developing country will create conveniences and economic benefits to farmers who produce products in the fruit and vegetable chain, as well as processors, exporters and consumers. It is much convinent and cheap for small and medium sized farmers to use Agricultural Cooperatives' specialized products/services such as getting selected seeds, cultivating, harvesting, transporting, sorting, processing and storing in cold stores. As a result, the quality of the products will be Generalization of scientific results 
maintained, time and expenses be reduced. For processors and export enterprises, there will be high quality and cheap products throughout the year. Because of its climate and other resources, Uzbekistan has great opportunites to produce high quality fresh fruit and vegetable products and export them as fresh or processed in regional and international markets. Storing and processing sectors are not well developed while available enough labor force and necessary climate conditions. However, export of products to the world markets is challenge for farmers and other actors of the fruit and vegetable value chain. A number of issues such as the lack of information and cold storage, the application of international standards and the making international agreements are very costly for individual players. The best option for farmers and other actors to deal with these problems is to establish and operate under the supervision of agricultural cooperatives. At present, agricultural cooperatives are not available in Uzbekistan. However, different types of services have been providing to farmers and processors by several state-owned companies. For example, "O'zbekoziqovqatxolding" holding company and Joint Stock Company "Uzagroexport" were organized in 2016 according to the decrees of the president of Uzbekistan to expand the export opportunities of the farmers and food processing companies of the country. In this regard, the main functions of these two organizations are following:

Deep marketing researches of global and regional markets of fruits and vegetables, search and development of new markets for export;

Establish regular contacts with trusted foreign buyers, make with partners long-term and short-term export contracts for fresh and processed fruit and vegetable products;

Organize annual international fruits and vegetables exhibitions and introduce Uzbek farmers and their products to the foreign partners;

Support to farmers to build, modernize cooling and logistics facilities by involving foreign partners; organization of production safe and high quality packaging materials by using the modern technologies and international experiences;

The introduction of modern export-oriented logistics systems, pre-export preparations such as selection, calibration and packaging of products in compliance with international requirements and standards;

In Uzbekistan, the agricultural products are produced by three different categories of entities: Farms, Dehkan farms (Private Peasantry) and Enterprises carring out agricultural activities. 
The chart-3 indicates the number of africultural farms in years 20002016 in the Republic of Uzbekistan. As January 1, 2017 the number of farms was 132356,0 and their total area was 5806,2 thousand ha while area per farmer consisted of 44,0 ha.

Chart-3

\section{Number of agricultural farms in years of 2000-2016}

(Piece)

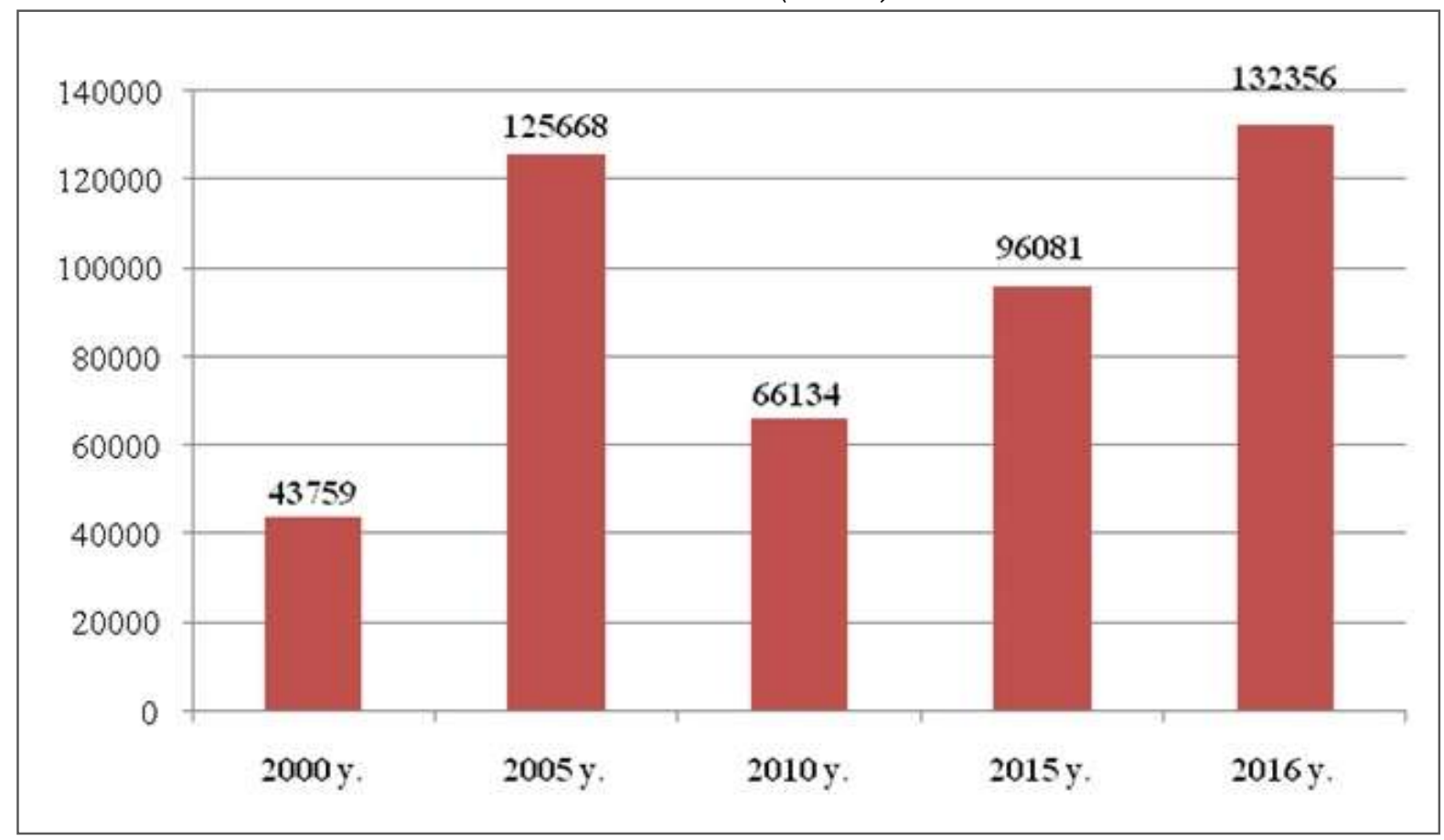

Source: Statistical Committee of the Republic of Uzbekistan. 2018

The reason of decresing the number of farms between 2005 and 2010 is associated with the government agricultural policy. According to it, between these years small farmers optimized and several small farmers united as one big farm to increase the efficiency. However, between the years of 2015 and 2016, government started to decrease the cotton fields and allocated fileds for horticulture based small and medium farmers.

Dehkan farms (Private Peasantry) is a small family based agricultural products producer, grows and sells agricultural products, which are produced on a parcel of land allocated to the head of the family for inherited lifetime as the personal merit.

The number of Dehkan farms was 4769,0 thousands as January 1, 2017 while it increased by 147,0\% compare to year 2000 (Chart-4).

Generalization of scientific results 
Chart-4

Number of Dehkan farms in Uzbekistan for years of 2000-2016

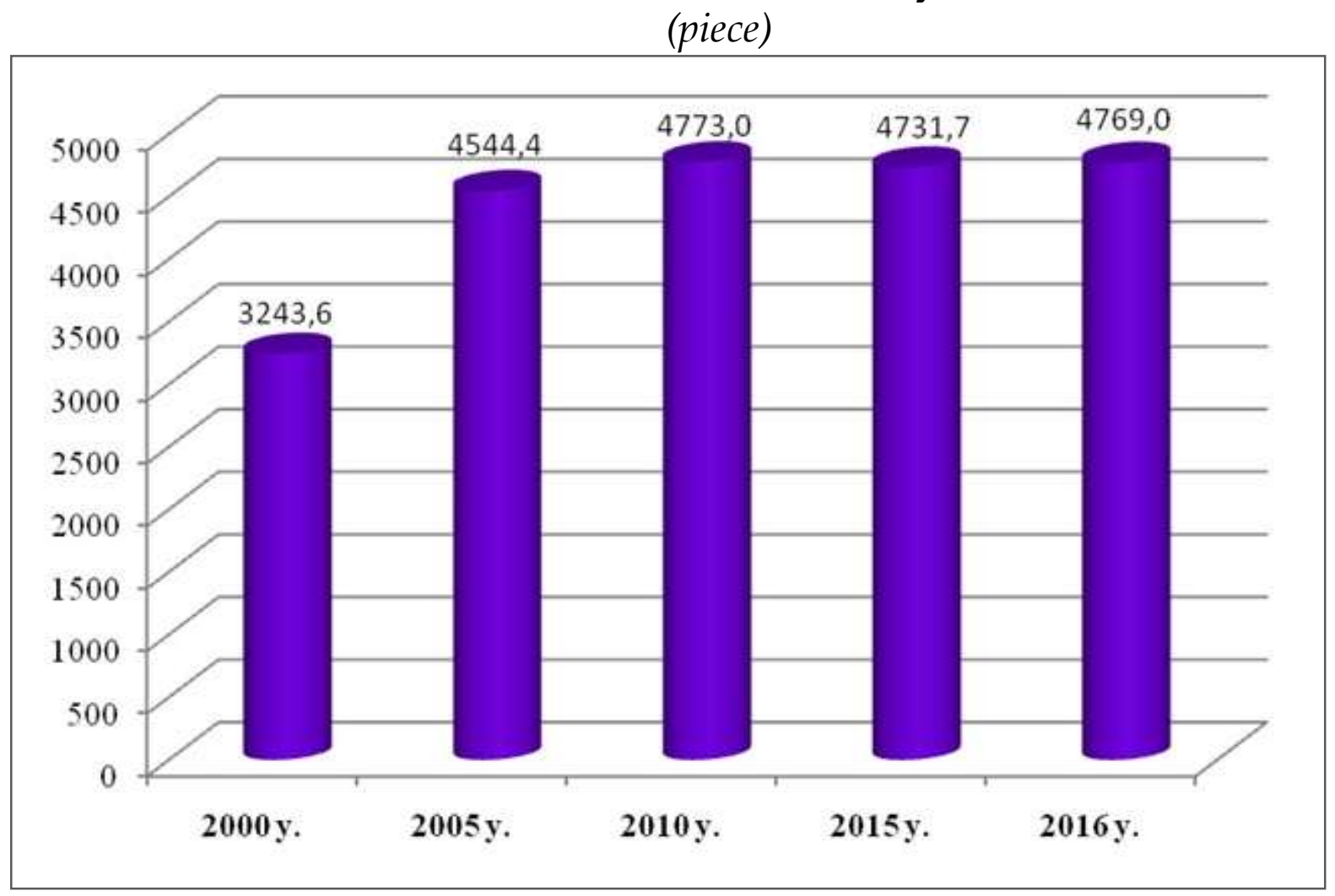

Source: Statistical Committee of the Republic of Uzbekistan. 2018

Enterprises carrying out agricultural activities are are legal entities that are engaged in the production of agriculture and livestock products and served the agricultural production processes. In recent years, the share of enterprises carrying out agricultural activities in all types of agriculture based entities is decreasing year by year. This means that farms and dehkan farms are developing very fast and their total production shares are also increasing accordingly.

As we see from the tendencies, the number of farms and dehkan farmers are increasing, fruit and vegetable production has been increasing for last two years. Since the much share of production produced in two seasons (summer and autumn), product loss percentage is staying as high because of marketing and storage issues. In this case, farmers are needed cooperatives to minimize their costs for marketing and storage by joining their efforts and increase their profit and strengthen market position.

We provide following recommendations for the development of agricultural cooperatives in the Republic of Uzbekistan:

Generalization of scientific results 
- Develop legal framework of cooperatives and support farmers, processors and exporters by the government for organizing the cooperatives;

- $\quad$ Provide different privileges to agricultural cooperatives;

- Partial or complete liberation of the cooperative and its members in practice of taxation for the costs associated with their participation in agricultural and food exhibitions both inside the country and abroad, in order to encourage the export of vegetables and fruits;

- Allocation of land plots to cooperatives that necessary for the establishment of logistics centers, cooling, storage and other supporting activities for its members; and granting unused government premises to cooperatives for long-term lease with favorable terms;

- Establish Agricultural Cooperatives Service Division within the Ministry of Agriculture of the Republic of Uzbekistan and delegate responsibility to the Division to develop cooperative activities in the country.

\section{Literature review}

Ў.Умурзаков. Реорганизация сельскохозяйственных предприятий: основные варианты и процедурные аспекты. Пахтачилик журнали. №3. 1998 йил. (Umurzakov, U. 1998. Reorganization of agricultural enterprises: basic options and procedural aspects. Journal of Pakhtachilik. No. 3. 1998)

У.Умурзаков, С.Эшматов. Мева-сабзавотчиликда қиймат занжири тахлили. Узбекистон иқтисодий ахборотномаси журнали. №1. 2017 йил. (Umurzakov, U., Eshmatov, S. 2017. Value chain analysis in fruit and vegetable production. Journal of Economic Trends Uzbekistan. No. 1. 2017)

У..Умурзаков, С.Эшматов. Мева-сабзавотчилик қиймат занжирида вертикал ва горизонтал интеграциянинг ахамияти. Молиячи маълумотномаси журнали. №8 (68). 2017 йил. (Umurzakov, U., Eshmatov, S. 2017. Importance of vertical and horizontal integration in fruit and vegetable value chain. Journal of Financial worker's handbook. No.8 (68). 2017)

С.Эшматов. Мева-сабзавотчилик қиймат занжири буйича хорижий тажриба. AGRO ILM журнали. №1 (45). 2017 йил. (Eshmatov, S. 2017. Foreign experience in fruit and vegetable chain value. Journal of AGRO ILM. No.1 (45). 2017)

С.Эшматов. Мева-сабзавотчиликда қиймат занжирининг мохияти. Молиячи маълумотномаси журнали. №9 (57). 2016 йил. (Eshmatov, S. 2016. The essence of the fruit and vegetable value chain. Journal of Financial worker's handbook. No.9 (57). 2016)

Generalization of scientific results 
Agricultural Cooperatives in Europe. Main Issues and Trends. Cogeca meeting. Brussel, 2010.

Bijman, J. 2016. Agricultural Cooperatives in the Netherlands: Key success factors. Paper. International Summit of Cooperatives 2016.

Bijman, J., Muradian, R., and Cechin, A. 2011. Agricultural cooperatives and value chain coordination. www.researchgate.net

Burt L. (2004). A Brief Introduction to Agricultural Cooperatives. Oregon State University, Corvallis, Oregon, United States.

Dardak, R. 2015. Cooperative Movement in the Supply Chain of Agricultural Products: Way Forwards. The Malaysian Agricultural Research and Development Institute.

Development of agricultural cooperatives in the EU in 2014. Report. Copa-Cogeca, Brussel 2015.

General Confederation of Agricultural Cooperatives of the European Union.

Hanf, J. 2014. Processor driven integration of small-scale farmers into value chains in Eastern Europe and Central Asia. A synthesis paper. FAO 2014

Hanisch, M. 2009. Global Cooperative linkages? - The Challenge To Harmonize local with global economies. Humboldt University Berlin, Department of Agricultural Economics and Social Sciences, Division of Cooperative Sciences.

Hendrikse G.W.J. (2004), Restructuring Agricultural Cooperatives. Erasmus University Rotterdam, Rotterdam School of Management, Rotterdam, Holland.

Hobbs J.E, Fearne A. \& Spriggs J (2002). Incentive structures for food safety and quality assurance: An international comparison, Food Control, Vol. 13, pp. 77-81

http://www.copa-cogeca.be/Menu.aspx

Makri, D., Skandalou, A., Manthou, V., and Vlachopoulou, M. 2011. ICT applications in the supply chain of Greek agricultural cooperatives. Paper presented at HAICTA, volume 1152 of CEUR Workshop Proceedings, page 89-102. CEUR-WS.org, (2011).

Manalili, N. 2003. Linking Farmers to Markets Through Cooperatives Vegetables Supply Chain Redesign Options for Kapatagan, Mindanao, Philippines. Paper presented at the Australian Agricultural and Resource Economics Society Conference, Perth, WA, 11-14 February 2003. 
Mei, X., Han, Z., and Chen H. 2009. Study on the Cost Management Based on the Cooperative Value Chain. International journal of business and management. Vol. 4, No. 6

Popovic, R. 2013. Processor driven integration of small farmers into value chains in Republic of Serbia. Paper. FAO, 2013.

Ruete, M. 2014. Inclusive Investment in Agriculture: Cooperatives and the role of foreign investment. International Institute for Sustainable Development. Policy Brief \#2.

The International http://ica.coop/en/what-co-operative

Co-operative Alliance.

2017.

University of California Cooperative Extension Small Farm Program. 2012. http://sfp.ucdavis.edu/cooperatives/what_is/\#ag

Walter, D., and Rainbird, M. 2007. Cooperative innovation: a value chain approach. Journal of Enterprise Information Management. Vol. 20 Iss 5 pp. $595-607$

\section{Other Relevant Literature Not Cited}

Boland, M., J. Lusk, and D. Barton. "Producer Investment Factors in Food-Processing Cooperatives." Invited paper presented at the NCR-194 Research on Cooperatives meeting in Kansas City, MO, November 14 and 15, 1999.

Cook, M.L. "The Future of U.S. Agricultural Cooperatives: A NeoInstitutional Approach." American Journal of Agricultural Economics, 77 (December): 1153-1159.

Cooperatives: Issues and trends in developing countries. Workshop Report, Perth, Australia, March 24-25, 2003. Published by Australian Centre for International Agricultural Research, ACIAR Technical Report No. 53, 2004.

Kenkel, P. "Evolving Credit Needs of Cooperatives and ProducerOwned Businesses." Invited paper presented at the "Serving the Changing Financial Needs of American Farmers and Ranchers, 2005 - 2016": A project of Farm Credit Horizons project meeting. Oklahoma State University, the USA, Februrary 11, 2005.

Kenkel, P., R.B. Holcomb and E. Ac Bol. "How Do Cooperative Managers and Board Members View Value-added Enterprises and New Generation Cooperative Structures?" Visions Volume 72, No. 2 pp. 28-35, Dec. 2000. 
Smith, S.C and Rothbaum, J. 2013. Cooperatives in a Global Economy: Key Economic Issues, Recent Trends, and Potential for Development. George Washington University. 